\title{
THE ISSUE OF THE HOLOCAUST TEACHING AT PRIMARY AND SECONDARY SCHOOLS IN SLOVAKIA
}

\author{
LUCIÁNA HOPTOVÁ \\ Institute of History, Faculty of Arts, University of Prešov in Prešov \\ Ul. 17. novembra 1, 08001 Prešov, Slovak Republic \\ E-mail address: luciana.hoptova@gmail.com \\ ORCID: https://orcid.org/0000-0001-6757-8278
}

\begin{abstract}
Aim. The primary aim of the study is to examine how the issue of the Holocaust is integrated into the teaching of history at primary and secondary schools (especially grammar schools) in the Slovak Republic. The secondary aim is to present methodological ideas, suggestions and recommendations for teaching the Holocaust in Slovak schools.

Methods. The subject of the study is an analysis of basic state educational documents defining the compulsory content of education and training for the school subject of history at primary school and grammar school, thus the State educational programme for lower secondary education (second stage of primary school) and the State educational programme for grammar schools (completed secondary general education), with emphasis on the Holocaust. The method of analysis is applied to textbooks of history that contain information about the Holocaust. The study also includes a detailed analysis of methodological recommendations and suggestions prepared by the Ministry of Education, Science, Research and Sport of the Slovak Republic and the National Institute for Education to assist teachers in teaching the Holocaust issue. The study is supplemented by knowledge from educational practice that was obtained through an interview method with 15 teachers of history.

Results. The Holocaust is an integral part of teaching history at primary schools and grammar schools. Students get acquainted with the Holocaust issue in Slovak and global historical context in the $9^{\text {th }}$ year of primary school and the $3^{\text {rd }}$ year of grammar school within a four-year educational programme. The basic content of education is defined in the educational standards of state educational programmes. Teachers can specify and elaborate it even more while teaching of history. Its development is aided not only by textbooks of history but also by various educational and professional activities defined in various methodological materials and manuals.

Key words: Holocaust, history, primary school, grammar school, Slovak Republic
\end{abstract}




\section{INTRODUCTION}

We are witnessing an increase in extremist, racist, xenophobic manifestations and other forms of intolerance in recent years in Slovakia. The radicalisation of the political scene, the fear of the unknown but also ignorance or insufficient information about horrors and atrocities which have been committed against innocent people in the past have a share in this societal phenomenon.

We consider the Holocaust to be the greatest manifestation of human cruelty, even more, the failure of men. For many years, the topic of the Holocaust and the deportations of Jews from Slovakia during World War II were taboo. This was caused mainly by the fact that part of the citizens of the war Slovak Republic (1939-1945) cooperated with Nazi Germany and participated in the Holocaust. Currently, the issue of the Holocaust in Slovak and global historical contexts is the subject of several scientific pieces of research, monographs and studies. However, this topic has an important place in the educational process, especially in history teaching.

The educational process in Slovakia is governed by the Ministry of Education, Science, Research and Sport of the Slovak Republic (hereinafter also the Ministry of Education). The position of the Ministry of Education, as well as its tasks, are defined in Act No. 596/2003 Coll. on state administration in education and school self-government, in the amendments and supplements to some laws (Právny a informačný portál Slov-Lex, 2020), and Statute of the Ministry of Education, Science, Research and Sport of the Slovak Republic (Ministerstvo školstva, vedy, výskumu a športu Slovenskej republiky, 2010). One of the main tasks of the Ministry of Education is to issue state educational programmes, the most important curricular documents, which define the compulsory content of education at various types of the school system - pre-primary educational institutions, primary and secondary schools. The exceptions to this school system are higher educational institutions, colleges and universities, whose status, tasks and content of education are governed by individual legal regulations.

The current educational process at primary and secondary schools is carried out in accordance with innovated state educational programmes. These are based on the democratic and humanistic values of society and the emphasis is mainly on the formulation of requirements for output within a thematic unit, grade or level of educational system depending on the nature of the school subject. These requirements are formulated in the part of the programme the educational standard, which consists of two parts, namely performance standard and content standard. The basic learning objectives are specified in the performance standard, which can be specified and developed by teachers in the teaching process. The content standard determines the minimal content of education, which is defined by terms, key component units of the internal structure of learning content (Kmet', 2017).

One of the school subjects which is characterised in innovated state educational programmes is history. History is taught as a compulsory school subject 
at primary school and all types of secondary schools. At primary school history is taught at its second stage (lower secondary education), $5^{\text {th }}-9^{\text {th }}$ school years. The highest hour subvention for history teaching is in the last school year $-9^{\text {th }}$.

In terms of history teaching at secondary schools, the largest representation is at grammar schools, which provide complete secondary general education for the young population. History is taught as a compulsory school subject in the $1^{\text {st }}-3^{\text {rd }}$ school year of grammar school with a four-year educational programme. At other types of secondary schools-secondary technical schools and conservatoires - history is taught only in lower grades in limited form because this school subject does not form the main component of the educational process. Considering these facts, this study focuses on the teaching of history at grammar schools.

The innovated state educational programmes consist of educational spheres, areas, where the issue of related school subjects belong. History is one of the general education subjects at primary school (second stage) and at grammar school, belonging to the educational field of Man and Society. It is made up of two important school subjects - geography and civics (Ministerstvo školstva, vedy, výskumu a športu Slovenskej republiky, 2015a, 2015b).

The main function of the school subject history is "cultivating pupil's historical consciousness as holistic personalities and preserving the continuity of historical memory in terms of passing on historical experience, whether local, regional, national, European or global perspective" (Štátny pedagogický ústav, 2015b, p. 2). During the history teaching, students become acquainted with historical phenomena and processes that have fundamentally influenced the development of Slovak and global societies. The teaching places special emphasis on the history of the $19^{\text {th }}$ and $20^{\text {th }}$ centuries, which is well-founded by the fact that it is possible to find the roots of current social phenomena and social problems in such recent events (Ministerstvo školstva, vedy, výskumu a športu Slovenskej republiky, 2015a, 2015b). One of the topics to which history teachers at primary and secondary schools pay increased attention is the Holocaust.

\section{THE TOPIC OF THE HOLOCAUST IN STATE EDUCATIONAL PROGRAMMES}

The topic of the Holocaust is taught at the second stage of primary school in the $9^{\text {th }}$ school year. In accordance with the innovated State educational programme for lower secondary education, the Holocaust is a part of two thematic units - Scenes of World War II and The Slovak State (1939-1945). The first unit is devoted to war events in a global historical context. Following the programme, one of the goals of the performance standard is: "to process the Holocaust to a specific story" (Štátny pedagogický ústav, 2015b, p. 15). In the content standard, we can find terms such as keywords "Holocaust" and "concentration camps" (Štátny pedagogický ústav, 2015b, p. 15). 
The second thematic unit, The Slovak State (1939-1945), focuses on the development of World War II in Slovakia. In the performance standard, it is stated that the goal is "to specify gradual restrictions of the human rights and freedom of Jewish citizens" (Štátny pedagogický ústav, 2015b, p. 16). Key terms such as "totalitarian regime," "the Jewish Code," or "deportations" are defined in the content standard (Štátny pedagogický ústav, 2015b, p. 16).

Table 1

The thematic unit The Slovak State (1939-1945) in the educational standard History - for lower secondary education.

The Slovak State (1939-1945)

\begin{tabular}{|c|c|}
\hline Performance standard & Content standard \\
\hline $\begin{array}{l}\text { At the end of the } 9^{\text {th }} \text { year of primary school, a pupil } \\
\text { knows/can: } \\
\text { - compare the political system of the Slovak State with the } \\
\text { political system of the Czechoslovak Republic, } \\
\text { - recognise the relations between Germany and the } \\
\text { Slovak State, } \\
\text { - evaluate the economic and cultural development of the } \\
\text { Slovak State, } \\
\text { - specify gradual restrictions of the human rights and } \\
\text { freedom of Jewish citizens, } \\
\text { - assess the importance of the Slovak National Uprising, } \\
\text { - work with school historical sources from the given } \\
\text { historical period. }\end{array}$ & $\begin{array}{l}\text { totalitarian regime } \\
\text { the Jewish Code } \\
\text { deportations } \\
\text { resistance } \\
\text { the Slovak National } \\
\text { Uprising }\end{array}$ \\
\hline
\end{tabular}

The State educational programme for lower secondary education (second stage of primary school) was approved by the Ministry of Education on $6^{\text {th }}$ February 2015, and valid since $1^{\text {st }}$ September 2015. However, this document has changed in recent years and several amendments have been accepted. Considering the school subject of history, the Amendment No. 2, of July 21, 2017, is very important because of the higher hour subvention for history teaching in the $9^{\text {th }}$ class. Hour subvention has been increased from two to three lessons per week. This change came into force in the school year 2019/2020 (Ministerstvo školstva, vedy, výskumu a športu Slovenskej republiky, 2017).

At grammar schools, students start to study the topic of the Holocaust in the $3^{\text {rd }}$ grade. In the innovated State educational programme for grammar schools (completed secondary general education), school subject history, the issues are defined in two thematic units. The first unit is called "World War II" and focuses on the war events in the world. Following the performance standard, after taking the course, students should be able to determine the main causes of World War II, characterise its course and consequences, and develop the causes of forced migration of the population after the war. Regarding the issues we have examined, the performance standard states: "to substantiate the Holocaust in a specific story" (Štátny pedagogický ústav, 2015a, p. 19). Among keywords defined in the 
content standard section, we find the terms "Holocaust" and "Righteous Among the Nations" (Štátny pedagogický ústav, 2015a, p. 19).

The second thematic unit is devoted to Slovak history and it is called "The Slovak State (1939-1945)." In the performance standard, we find its aim: "to clarify the solution of the Jewish issue in a specific story" (Štátny pedagogický ústav, 2015a, p. 20). The content standard defines terms related to Jewish issue - "anti-Semitism" and "Aryanisation" (Štátny pedagogický ústav, 2015a, p. 20).

The innovated State educational programme for grammar schools (completed secondary general education) was ratified by Ministry of Education on $20^{\text {th }}$ March 2015 and became valid on $1^{\text {st }}$ September 2015. This document has also been changed and complemented several times in recent years. Regarding the issues discussed therein, the Amendment No. 1 is very important, which concerns not only grammar schools but also other types of secondary schools. Amendment No. 1 became valid on $1^{\text {st }}$ September 2016 and it states that the aim of teachers is to focus on the effective and objective prevention of manifestations of racism, xenophobia, anti-Semitism, extremism, and other forms of intolerance. The amendment mentions several suitable activities that teachers should include in the educational process at secondary schools (Ministerstvo školstva, vedy, výskumu a športu Slovenskej republiky, 2016).

One of the first activities that the Ministry of Education recommends to perform are excursions to concentration camps and Holocaust memorial sites located in Slovakia or abroad. Recommended excursions in Slovakia are The Holocaust Museum in Sered', The Museum of Jewish Culture in Bratislava, The Museum of the Slovak National Uprising in Banská Bystrica, The Nation's Memory Institute in Bratislava, The Roma Holocaust Memorial in Dubnica nad Váhom, and The Roma Holocaust Memorial in Dunajská Streda. As for foreign excursions, students should visit, e.g., the concentration and extermination camp Auschwitz-Birkenau (Poland) or the concentration camp in Terezín (Czech Republic).

The second activity defined in the amendment concerns visits to towns and villages where Jews, Romani population, ethnic, political and social groups have been affected by Nazi repression. The Ministry of Education recommends visiting places representing mementoes of Slovak and Czech history. These villages are, for example, Kl'ak, Ostrý Grún̆, or Čierny Balog in Slovakia, as well as Brno, Lidice, or Ležáky in the Czech Republic. These towns and villages became the victims of Nazi rage during World War II.

Another activity mentioned in the amendment is the implementation of projects and competitions aimed at expressing the students' attitudes to the topic or historical events called "Who does not know one's own history never learns from it and keeps repeating it." As a part of this activity, the Ministry of Education proposes to implement a project Research into past, the aim of which is to inform students with the life stories of Holocaust victims.

In the amendment the Ministry of Education also recommends secondary schools to organise artistic and literary projects, as well as competitions with historical, juridic and value objects. The organisation of discussions with still- 
-living participants of Nazi fascist persecution and terror, or with their family members, is the last recommended activity defined in this material for secondary schools.

\section{THE TOPIC OF THE HOLOCAUST IN HISTORY TEXTBOOKS}

The content of school subject history is not only defined by state educational programmes but also elaborated in history textbooks, which are a basic teaching aid for pupils. Current history textbooks used in the teaching process at Slovak schools are divided into individual thematic units and then into individual topics. Thematic units are arranged chronologically and their content consists of Slovak and world history.

Regarding the discussed issues, two history textbooks are key for us. The first textbook is intended for pupils of $9^{\text {th }}$ year of primary school and the second one for students of the $3^{\text {rd }}$ year grammar schools and secondary schools. Both history textbooks were accredited by the Ministry of Education, Science, Research and Sport of the Slovak Republic. Experts, historians, didacts, and history teachers with many years of experience participated in the writing of the textbooks.

The history textbook for $9^{\text {th }}$ year of primary schools contains five thematic units. Pupils study the issue of the Holocaust in the third thematic unit called "World War II," specifically in two topics. The first topic that presents the development of world events is "Life in an occupied Europe." In the introduction to the explanatory text, pupils are informed about the development and war situation in Europe in 1941 and the subjugation of individual countries by Nazi Germany. The second part of the explanatory text is devoted to Nazi terror in the occupied countries and the murder of Jews in Europe. The authors of the textbook describe to the pupils not only cruel treatment of the Jewish population by the Nazis but also of the members of other nations, ethnic and social groups who did not support Nazi ideology. The conclusion of the explanatory text is devoted to the uprising of the Jews in the Warsaw Ghetto in 1943 but there is also information about its suppression. The explanatory text is complemented by contemporary photographs depicting children in the Warsaw Ghetto, as well as historical photographs depicting the selection of people in the concentration and extermination camp Auschwitz-Birkenau. The horror of the Holocaust is also introduced to pupils through the historical source memories of the German political prisoner in the concentration camp. Part of this topic is also an explanation of the basic concepts that the pupil finds in the text. These terms are - Holocaust, deport, selection (Kováč, Kratochvíl, Kamenec, \& Tkadlečková, 2019).

While the first topic in the history textbook for the $9^{\text {th }}$ year is devoted to the Holocaust from the perspective of world history, the second topic "What was the Slovak State like?" focuses on the development of the Slovak State, which since $21^{\text {st }}$ July 1939 bore the official name of the Slovak Republic. Although 
most of the explanatory text is devoted to internal political development, in the conclusion we can find information how the Jewish issue was solved in the Slovak State, including the analysis of the Jewish Code, which limited the basic human and civil rights of Jews. Various statements of the former Slovak political officials, elites, or slogans published in leaflets can be used for reflection and subsequent discussion for pupils. The explanatory text is completed by old photographs which depict not only leading Slovak politicians of that time - Vojtech Tuka, Alexander Mach - but also the Jewish population during deportations (Kováč, Kratochvíl, Kamenec, \& Tkadlečková, 2019).

Grammar school students study the issue of the Holocaust in the history textbooks in the $3^{\text {rd }}$ school year of grammar schools and secondary schools, specifically in two thematic units - "The World War II" and "The Slovak Republic 1939-1945." The first-named unit focuses on war events in a global historical context and the Holocaust is the subject of two themes: "The great phases of the World War II" and "Beyond the front lines - life in the time of war." In the first topic, the Holocaust is mentioned during the German attack and subsequent occupation of Poland in 1939. Students can read briefly about the new occupation order and the creation of concentration and extermination camps on the Polish territory. The authors of history textbooks focus their attention on Poland because this country was the most exposed to cruel oppression at the beginning of World War II (Letz, Tonková, \& Bocková, 2015).

A much larger space is devoted to the Holocaust in the theme "Beyond the front lines - life in the time of war." The history textbook describes the attitude of Adolf Hitler, the Nazi leader, to the Jewish population. He considered them to be the main reason for all evil existing in Germany and around the world. Students are informed about Nazi Germany's plans for a final solution to the Jewish issue. The topic is supplemented by historical photographs showing the atrocities committed against the Polish and Belarusian populations. In the textbook, there is a photograph with the description showing the gate to the concentration and extermination camp Auschwitz-Birkenau (Letz, Tonková, \& Bocková, 2015).

In the second thematic unit, "The Slovak Republic 1939 - 1945," we can see the issue of Holocaust in the topic called "Fates of Undesirables." Emphasis is placed to characterise individual stages of persecution of Jews in the Slovak Republic. In the text, special attention is paid to the deportation of Jews to concentration and extermination camps. The explanatory text also analyses the government regulation containing a set of anti-Jewish regulations - the Jewish Code, which was adopted on September 9, 1941. The authors of this history textbook do not forget to introduce to students the negative attitude of the Vatican and Slovak Bishops towards the deportations of the Jewish population in the explanatory text. Students can also get to know the attitude of Slovak bishops from the historical source - "The Memorandum of Slovak Catholic Bishops of October 7, 1941, about the Jewish Code." The conclusion of this topic is devoted to a special issue, the persecution of the Romani population, also the Roma Holocaust. For a better understanding of the contexts, the expla- 
natory text is completed by a pictorial addition - historical photographs of Jews in the labour camp and the deportation of the Jewish population in 1942. The theme also includes two cartoons: one of them aims against Jews and the other one aims against Aryanisers. The authors include them in the textbook for the students to reflect on their meaning and then discuss in history lessons (Letz, Tonková, \& Bocková, 2015).

Educational practice shows us that the teachers in history teaching also use additional teaching texts. As it is possible to conclude from the research we have done, the supplementary textbooks - The solution to the Jewish question in Slovakia during 1938 - 1945 - are extremely important. Texts dealing with the topic of the Holocaust in Slovak historical context are intended for primary and secondary school students. They contain examples of archival documents, historical photographs but also authentic memoirs of the Holocaust survivors. The authors of the publication aim to make students think about the feelings of the victims who experienced this horror and to express their personal attitude to this issue (Mešt́an, Plesníková, Kičková, \& Korčok, 2013).

\section{METHODOLOGICAL RECOMMENDATIONS AND CURRENT TRENDS IN TEACHING THE TOPIC OF THE HOLOCAUST}

As we stated in the introduction of the study, we have recently witnessed an increase in manifestations of extremism, racism and xenophobia in Slovakia. These intolerant manifestations are increasingly finding their followers even among primary and secondary students. The National Institute for Education (organisation of the Ministry of Education, Science, Research and Sport of the Slovak Republic), which provides professional and methodological counselling to primary and secondary schools, has responded to this current social situation by publishing in 2019 a professional material which guides teachers' progress in the teaching of the Holocaust topic. The document "Methodological recommendations for teaching the Holocaust at primary schools (lower secondary education) and secondary schools (upper secondary education) in the Slovak Republic" was prepared by the National Institute for Education in cooperation with experts dealing with Holocaust issues in Slovak and global historical context (Metodický portál Štátneho pedagogického ústavu, 2019). The methodological material follows the educational standards of history subject and amendments to state educational programmes. The aim is to offer teachers ideas, suggestions and recommendations for teaching about the Holocaust. Their incorporation into teaching is intended to increase students' awareness of the atrocities committed against innocent people, which seeks to ultimately reduce the level of intolerance among young people.

The first recommendation in the methodological material concerns the use of an increased hour subvention for the school subject of history at primary school. As it was mentioned above, since the school year 2019/2020, hourly subvention for the subject of history in the $9^{\text {th }}$ year has been increased from 
the original two hours to three hours per week. This one extra hour should be devoted to the teaching of the Holocaust in the Slovak and global historical context (Metodický portál Štátneho pedagogického ústavu, 2019).

The implementation of historical excursions for primary and secondary schools is the idea of the second methodological initiative. It is directly related to Amendment No. 1 to the state educational programmes for grammar schools, secondary technical schools and conservatoires, which is valid since $1^{\text {st }}$ September 2016. Schools are recommended to visit the concentration and extermination camp Auschwitz-Birkenau or Sered' labour and concentration camp as well as some other museums and Holocaust Memorials in Slovakia or abroad, which-according to the amendment-should be a part of history lessons in the lower secondary education as well as the secondary education on at least one occasion (Metodický portál Štátneho pedagogického ústavu, 2019).

The methodological recommendation gives priority to visiting the Holocaust Museum in Sered', which was established in 2016 on the site of a labour and concentration camp. The museum is a memorial to the murdered Jews in Slovakia and offers several educational activities for students as well as professional and methodological assistance to teachers in explaining such a complex topic as the Holocaust (Beránek, 2017).

In the methodological material of the National Institute for Education, we can also find recommendations regarding the innovated State educational programme for lower secondary education (second stage of primary school) and the innovated State educational programme for grammar schools (completed secondary general education) for school subject of history. Following state educational programmes, the teachers of history should place increased emphasis on the aims and concepts contained in the educational standards. However, teachers should not forget to accomplish other general educational goals, especially developing cultural dialogue and open discussion as a basic principle of the functioning of history and history teaching in a democratic society (Metodický portál Štátneho pedagogického ústavu, 2019).

Students of primary and secondary schools can also study the topic of the Holocaust while studying other school subjects - Slovak language and literature, civics, ethics, religion, etc. Interdisciplinary dimension is the subject of other recommendations contained in this methodological material. It also encourages teachers to see specific suggestions on how to integrate the Holocaust topic into other school subjects. For example, in Slovak language lessons, it is recommended to write essays about the fate of people who became the victims of discriminatory laws and restrictions of the Nazi regime; in ethical education, it is suggested to lead a discussion with students about the values of human life, human dignity, freedom, fairness, or conscience; in civics, it is recommended for students to compare totalitarian and democratic regimes (Metodický portál Štátneho pedagogického ústavu, 2019).

Possibilities of how to approach the teaching of the Holocaust issue in the educational process are the subject of another part of the methodological material. Experts encourage teachers to use project-based teaching and mutual lear- 
ning to develop students' critical thinking and media skills. Their development is crucial because nowadays there are several disinformation conspiracy media propagating extremist information.

Other methods recommended by the experts from National Institute for Education and Holocaust include the method of the history of everyday life. The aim of this method is for the victims of the Holocaust to be perceived not only as numbers but as real human beings who experienced unimaginable horror during their lifetime. As a basis for this method, we can evidence e.g. preserved diaries of Holocaust victims, memoirs or other book publications focused on the Holocaust issue. The methodological material contains a list of publications that teachers can use during the teaching of history, or other school subjects. First of all, they can include perhaps the most famous diary in the world - The diary of Anne Frank. In recent years, a work called Mengele's girl. A true story of a Slovak woman who survived four concentration camps has become a very important and beneficial work for teaching the Holocaust in Slovak educational institutions. The book describes the memories of Viola Stern Fischer, who survived four concentration camps and was one of many victims of sadistic experiments carried out by doctor Josef Mengele (Stern Fischerová \& Homolová Tóthová, 2016).

Educational practice shows us that, in addition to the above-mentioned recommended works, teachers use other book publications in teaching about the Holocaust. These are mainly publications that depict the tragic fate of Slovaks. According to research conducted among the teachers of history, they consider a book Escape from hell as a very important publication. The main characters are Slovak Arnošt Rosina and Pole Czesław Mordowitz, who managed to escape from the concentration and extermination camp Auschwitz-Birkenau in 1944 (Šebo, 2017). Another book is a publication The number on your forearm is blue as your eyes. It is the story of Eva Umlauf, who was born in 1942 in a labour camp in the Slovak town Nováky and from there she was later deported to the concentration and extermination camp Auschwitz-Birkenau (Umlauf, 2018). "To get to Slovakia at any cost and to testify..." Dionýz Lénard and his escape from the Majdanek concentration camp is the title of another publication used by teachers in history lessons. Its main character is Slovak Dionýz Lénárd, who escaped from Majdanek concentration camp in 1942. After arriving at Slovakia, Dionýz Lénárd prepared a report that describes and testifies to the terrible conditions in the camp (Hlavinka, 2015).

The method of oral history, meaning narrated history, also has its significance in the teaching of the Holocaust. Its essence lies in the fact that it draws on the testimonies of people who survived the Holocaust or their relatives. At primary and secondary schools, the oral history method is realised by conversation or discussion. These can take place at school, but also in other institutions, e.g. in museums, synagogues, or at various memorials. The Holocaust Museum in Sered' has played a very important role in this way because it has been organising educational discussions with contemporary witnesses for students of primary and secondary schools (Beránek, 2017).

One of the ways to explain to students the real stories and memories of people who survived the Holocaust is also a video presentation of these 
conversations. In connection with this method, we found special interview in the professional material. It is a recording of an interview with Pavol Traubner, a well-known Slovak doctor of Jewish origin and honorary chairman of the Central Union of Jewish Religious Communities in the Slovak Republic (Metodický portál Štátneho pedagogického ústavu, 2019).

The methodological material published by the National Institute for Education also includes a list of films and television documentaries that can be used in history teaching. As for the films, older and newer film editions of world and Slovak productions are recommended. These foreign films are recommended: The Pianist, Schindler's List, The Boy in the Striped Pyjamas, and the Czech-Slovak-Polish film All My Loved Ones. There is the only one Slovak film - The Shop on Main Street - which was awarded the Oscar Film Prize. The central motif of this film is the story of Tono Brtko, who participated in the Aryanisation of the non-prosperous Jewish shop (Metodický portál Štátneho pedagogického ústavu, 2019).

In the context of television documentaries, it is recommended to present students a French documentary cycle Apocalypse: The World War II., historical and authentic videos from the concentration and extermination camp Auschwitz-Birkenau, and documents The Power of Good: Nicholas Winton and Nicky's Family. The last two are dedicated to Nicholas Winton, an important saviour of Slovak and Czech children, mostly of Jewish origin. On the threshold of war and the Holocaust, he was responsible for the rescue and subsequent transport of 669 children from the territory of occupied Czechoslovakia to Great Britain (Metodický portál Štátneho pedagogického ústavu, 2019).

For a better approach to the reality of the Holocaust on the territory of the war-torn Slovak Republic, the National Institute for Education recommends teachers to watch the biographical stories from the series Testimonies of the survivors. The stories were processed by the civic association Edah, whose main goal is to research Jewish history and make it accessible to the general public through various educational events and activities. More than twenty short stories are available on the Edah civic association's website - the fates of those who survived and left a legacy, as well as warnings for young generations (Edah, občianske združenie, n.d.).

On the website of the Methodological Platform of the National Institute for Education, teachers of history can also find other topics and material for teaching the Holocaust, apart from the methodological document analysed above. Complementary educational materials are dedicated to the labour and concentration camp in Sered' and are intended for pupils in $9^{\text {th }}$ year of primary schools and students of secondary school, especially grammar schools. These materials contain a textbook about the Sered' camp, which comprises historical photographs, archival documents, memoirs of prisoners, the glossary with special terminology, its explanation, used literature, questions and tasks to think about. Complementary educational material also includes worksheets to help teachers with this challenging issue (Metodický portál Štátneho pedagogického ústavu, 2019).

There is also a link to the virtual teaching educational aid, Labour camp Sered', among the complementary educational materials. This teaching aid was pre- 
pared as a result of the cooperation between the Ministry of the Interior of the Slovak Republic and the Holocaust Museum in Sered'. Thanks to this teaching aid which is something between a digital game and a documentary, students can go through the virtual space of the labour and concentration camp in Sered' and listen to the testimonies of the survivors (Ministerstvo vnútra Slovenskej republiky \& Múzeum holokaustu v Seredi, n.d.).

All these complementary educational materials were created mainly because the issue of the labour and concentration camp in Sered' is not sufficiently reflected in history textbooks for primary and secondary schools, or in the state educational programmes, even though the camp in Sered' is one of the important mementoes in Slovak history.

Methodological recommendations, suggestions, or complementary educational materials offer teachers the opportunity to deepen their knowledge as well as to learn new techniques for teaching the Holocaust, which are acquired during pedagogical-scientific conferences, professional lectures, educational seminars or workshops. Educational events are organised by the Ministry of Education, the National Institute for Education, museums, methodological centres, educational institutions or various civic associations. Especially educational seminars, professional lectures or programmes organised by the Museum of the Slovak National Uprising in Banská Bystrica and the Holocaust Museum in Sered', which both deal with the issue of the Holocaust in their research, are very beneficial. To continue education of teachers, the Museum of the Slovak National Uprising in Banská Bystrica offers the educational programme Ethnic Cleansing, Genocide, and Racial Intolerance in History. It brings new expertise in the field of solving the Jewish issue in Slovakia and Europe, as well as the persecution of Romani people in Slovakia, but it also reflects on the modern manifestations of racism, neo-Nazism and xenophobia (Múzeum Slovenského národného povstania, n.d.).

The Holocaust Museum in Sered' offers teachers and general public the educational seminars, educational events, and trainings which are focused on topics such as Persecution of Jews during the Slovak State, Labour Camps and Centres for Jews, Escapes from Camps of Death, Children and the Holocaust, and Righteous Among the Nations. Fates of the Jews after World War II (Slovenské národné múzeum, n.d.). In addition, the museum also organises scientific seminars with international participants, for instance the international seminar Capacity building training on fundamental rights, citizenship and learning from the Holocaust. The seminar took place in November 2016 and the museum cooperated in its organisation with the Yad Vashem in Jerusalem, the European Union Agency for Fundamental Rights and the Ministry of Foreign and European Affairs of the Slovak Republic (Beránek, 2017).

Primary and secondary school teachers can further deepen their knowledge of the Holocaust through various foreign educational programmes. One of them is the Holocaust Teacher Training Programme, which is an initiative of the U.S. Department of State, the Association of Holocaust Organisations and the United States Holocaust Memorial Museum in Washington. The programme, which is implemented in the summer months at selected schools in the USA 
and has more than 20 years of tradition, has long been financially supported by the Ministry of Education, Science, Research and Sport of the Slovak Republic and the U.S. Embassy in Slovakia. Until 2019, 32 teachers from Slovakia participated in this programme (U.S. Embassy in Slovakia, n.d.).

\section{CONCLUSIONS}

The Holocaust issue plays a very important role in the teaching of history. Elementary school students get acquainted with the Holocaust for the first time at lessons of history in the $9^{\text {th }}$ year of primary school and later they encounter the topic again in the $3^{\text {rd }}$ year of grammar school. The compulsory content of education and training about the Holocaust is defined in the educational standard of the State educational programme for lower secondary education (second stage of primary school) and the State educational programme for grammar schools (completed secondary general education), school subject history. The Holocaust is a part of the educational standards of thematic units related to World War II, in both Slovak and global historical context. Emphasis is placed not only on the definition of the basic concepts, such as the Holocaust, Aryanisation, anti-Semitism, deportations, Righteous Among the Nations, but also on the goals that have to be completed after studying these thematic units.

However, the basic teaching goals and concepts set in the educational standards can be specified by teachers in the process of teaching history. History textbooks, in particular, have to help to develop them. History textbooks for the $9^{\text {th }}$ year of primary schools and for the $3^{\text {rd }}$ year of grammar school and secondary schools offer teachers several thematic units in which the Holocaust is approached not only through an explanatory text, but also historical photographs, period sources, analysis of anti-Jewish measures, cartoons or different tasks to think about. Part of the history textbooks is also the topic of the murder of the Romani population, which is not reflected in educational standards despite the fact that it forms an integral part of both Slovak and European history.

Another topic that is not included in state educational programmes, and is given minimal attention in the history textbooks, is the issue of the labour and concentration camp in Sered'. Teachers can learn about various approaches to the teaching of Sered' camp and the Holocaust issue in history lessons during various professional seminars or by participating in home and foreign educational programmes. Proposals for teachers are also offered in the methodological materials issued by the Ministry of Education, Science, Research and Sport of the Slovak Republic and the National Institute for Education. Methodological materials help teachers not only deepen their knowledge of the Holocaust but also become acquainted with new techniques and educational activities that can be applied in the teaching of history.

Educational practice shows us that popular educational activities - such as discussion with survivors, projections of films and historical documents, or learning about the Jews' life stories through memoirs or other book publica- 
tions - help teachers to teach this complex issue. However, the realisation of historical excursions to various memorial places connected with the Holocaust is irreplaceable regarding the educational activities. From the research conducted among primary and secondary school teachers of history, we can conclude that excursions are most often organised to the Memorial and Museum Auschwitz-Birkenau, yet in recent years the number of excursions to the Holocaust Museum in Sered' and the Museum of the Slovak National Uprising in Banská Bystrica has increased.

From the teacher's point of view, the teaching of the Holocaust is one of the most demanding topics in history teaching. Through various educational activities applied to the educational process, the teachers of history develop students' cognitive, affective and psychomotor level of education. This consolidation helps students to form their opinions and attitudes, which are crucial in today's world of extremist, racist and xenophobic expressions and other forms of intolerance.

\section{REFERENCES}

[1] Beránek, M. (2017). Múzeum holokaustu v Seredi [Holocaust Museum in Sered']. Dejiny internetový časopis Inštitútu histórie FF PU v Prešove, 12(2), 140-142. Retrieved May 25, 2020, from http://dejiny.unipo.sk/PDF/2017/Dejiny_2_2017.pdf.

[2] Edah, občianske združenie. (n.d.). Filmy [Films]. Retrieved May 27, 2020, from http://www. edahfilm.sk/filmy/.

[3] Hlavinka, J. (2015). "Dôjst' silou-mocou na Slovensko a informovat..." Dionýz Lénard a jeho útek z koncentračného tábora Majdanek ["To get to Slovakia at any cost and to testify..." Dionýz Lénard and his escape from the Majdanek concentration camp]. Bratislava: Veda, Historický ústav SAV.

[4] Kmet', M. (2017). História a dejepis. (Vybrané kapitoly z didaktiky dejepisu) [History and history as a school subject. (Selected chapters from the didactics of history)]. Banská Bystrica: Belianium. Vydavatel'stvo Univerzity Mateja Bela v Banskej Bystrici.

[5] Kováč, D., Kratochvíl, V., Kamenec, I., \& Tkadlečková, H. (2019). 9 dejepis - Pátrame po minulosti [9 history - We are looking for the past]. Bratislava: Orbis Pictus Istropolitana, spol. s. r. o.

[6] Letz, R., Tonková, M., \& Bocková, A. (2015). Dejepis pre 3. ročník gymnázií a stredných škôl [History for $3^{\text {rd }}$ year of grammar and secondary schools]. Bratislava: Slovenské pedagogické nakladatel'stvo - Mladé letá, s. r. o.

[7] Meštan, P., Plesníková, V., Kičková, A., \& Korčok, M. (2013). Riešenie židovskej otázky na Slovensku v rokoch 1938 - 1945. Doplnkové učebné texty [The solution to the Jewish question in Slovakia during 1938 - 1945. The supplementary textbooks]. Šal'a: Edah, o. z.

[8] Metodický portál Štátneho pedagogického ústavu. (n.d.). Doplnkové edukačné materiály $k$ víučbe témy holokaust v základných a stredných školách [Complementary educational materials for teaching the Holocaust in primary and secondary schools]. Retrieved May 28, 2020, from https://www.statpedu.sk/sk/metodicky-portal/metodicke-podnety/nova-web-stranka-3. html.

[9] Metodický portál Štátneho pedagogického ústavu. (2019). Metodické odporúčania k vyučovaniu témy holokaust $v$ základných (nižšie stredné vzdelávanie) a stredných školách (vyššie stredné vzdelávanie) v Slovenskej republike [Methodological recommendations for teaching the Holocaust at primary schools (lower secondary education) and secondary schools (upper secondary education) in the Slovak Republic]. Retrieved May 25, 2020, from https://www.statpedu. sk/files/sk/metodicky-portal/metodicke-podnety/metodicke-odporucania-k-vyucovaniu-temy-holokaust-zakladnych-strednych-skolach.pdf.

[10] Ministerstvo školstva, vedy, výskumu a športu Slovenskej republiky. (2016). Dodatok č. $1 k$ štátnym vzdelávacím programom pre gymnáziá, stredné odborné školy a konzervatóriá [Amendment 
No. 1 to the state educational programmes for grammar schools, secondary technical schools and conservatoires]. Retrieved May 25, 2020, from https://www.minedu.sk/data/att/10211. pdf.

[11] Ministerstvo školstva, vedy, výskumu a športu Slovenskej republiky. (2017). Dodatok č. 2, ktorým sa mení Štátny vzdelávací program pre primárne vzdelávanie - 1. stupeň základnej školy a nižšie stredné vzdelávanie - 2. stupeň základnej školy [Amendment No. 2 to the State educational programme for primary education - first stage of primary school and for lower secondary education - second stage of primary school]. Retrieved May 25, 2020, from https://www. minedu.sk/data/att/11991.pdf.

[12] Ministerstvo školstva, vedy, výskumu a športu Slovenskej republiky. (2015a). Štátny vzdelávací program pre gymnáziá (úplné stredné všeobecné vzdelávanie) [State educational programme for grammar schools (completed secondary general education)]. Retrieved May 25, 2020, from https://www.minedu.sk/data/att/7900.pdf.

[13] Ministerstvo školstva, vedy, výskumu a športu Slovenskej republiky. (2015b). Štátny vzdelávací program pre nižšie stredné vzdelávanie - 2. stupeň základnej školy [State educational programme for lower secondary education - second stage of primary school)]. Retrieved May 25, 2020, from https://www.minedu.sk/data/att/7500.pdf.

[14] Ministerstvo školstva, vedy, výskumu a športu Slovenskej republiky. (2010). Štatút Ministerstva školstva, vedy, výskumu a športu Slovenskej republiky [Statute of the Ministry of Education, Science, Research and Sport of the Slovak Republic]. Retrieved May 24, 2020, from https:/ / www.minedu.sk/statut-ministerstva-skolstva-vedy-vyskumu-a-sportu-sr/.

[15] Ministerstvo vnútra Slovenskej republiky, \& Múzeum holokaustu v Seredi. (n.d.). Pracovný tábor Sered' [Labour camp Sered']. Retrieved May 28, 2020, from https://muzeum.new.prevenciakriminality.sk/.

[16] Múzeum Slovenského národného povstania. (n.d.). Kontinuálne vzdelávanie. Etnické čistky, genocídy, rasová intolerancia v dejinách [Continuing education. Ethnic cleansing, genocide, and racial intolerance in history]. Retrieved May 29, 2020, from http:// www.muzeumsnp.sk/vzdelavanie/kontinualne-vzdelavanie/etnicke-cistky-genocidyrasova-intolerancia-v-dejinach-2/.

[17] Právny a informačný portál Slov-Lex. (2020). Zákon č. 596/2003 Z. z. o štátnej správe v školstve a školskej samospráve a o zmene a doplnení niektorých zákonov [Act No. 596/2003 Coll. on state administration in education and school self-government, in the amendments and supplements to some laws]. Retrieved May 24, 2020, from https://www.slov-lex.sk/pravne-predpisy/ SK/ZZ/2003/596/20200425.

[18] Slovenské národné múzeum. (n.d.). Múzeum holokaustu $v$ Seredi. Vzdelávanie [Holocaust Museum in Sered'. Education]. Retrieved May 29, 2020, from https://www.snm. sk/?muzeum-holokaustu-vzdelavanie.

[19] Stern Fischerová, V., \& Homolová Tóthová, V. (2016). Mengeleho dievča. Skutočný príbeh Slovenky, ktorá prežila štyri koncentračné tábory [Mengele's girl. A true story of a Slovak woman who survived four concentration camps]. Bratislava: Ikar, s. r. o.

[20] Šebo, J. (2017). Útek z pekla [Escape from hell]. Bratislava: Marenčin PT, spol. s. r. o.

[21] Štátny pedagogický ústav. (2015a). Dejepis - gymnázium so štvorročným a pätročným vzdelávacím programom. Vzdelávací štandard [History - the grammar school wiht four-year and fiveyear educational programme. Educational standard]. Retrieved May 25, 2020, from https:// www.statpedu.sk/files/articles/dokumenty/inovovany-statny-vzdelavaci-program/ dejepis_g_4_5_r.pdf.

[22] Štátny pedagogický ústav. (2015b). Dejepis - nižšie stredné vzdelávanie. Vzdelávací štandard [History - for lower secondary education. Educational standard]. Retrieved May 25, 2020, from https://www.statpedu.sk/files/articles/dokumenty/inovovany-statny-vzdelavaciprogram/dejepis_nsv_2014.pdf.

[23] Umlauf, E. (2018). Č́slo na tvojom predlaktí je modré ako tooje oči [The number on your forearm is blue as your eyes]. Žilina: Absynt.

[24] U.S. Embassy in Slovakia. (n.d.). Holocaust Teacher Training Program. Retrieved May 29, 2020 from https://sk.usembassy.gov/education-culture/professional-exchange-programs/ holocaust-teacher-training-program/. 